\title{
THE IMPACT OF THE TAX SYSTEM STRUCTURE ON THE NARROWING OF INCOME DISPARITIES IN OECD COUNTRIES ${ }^{1}$
}

\author{
Malgorzata Mazurek-ChwiejCzak ${ }^{2}$
}

Abstract

\begin{abstract}
Social disparities have a common and consistent character in the vast majority of contemporary countries. The level of income inequality in OECD countries has grown in the past 30 years and is still rising. Taxes and tax systems, aside from social transfers, are fiscal instruments widely used in compensation policy.

The aim of the article is to define the optimal structure of tax systems (i.e. the share of different tax categories in tax revenues) in terms of narrowing income disparities. To achieve this aim, scatter diagrams have been used. For the purpose of the article a tentative hypothesis has been formulated that the optimal tax system in terms of narrowing income disparities is characterised by a relatively large share of Personal Income Tax and at the same time a relatively low share of consumption taxes in tax revenues. The detailed analysis is focused on the countries for which the full data is available. The group of countries covers some "old" member states of the European Union (Austria, Belgium, Finland, Greece, Ireland, Italy, Luxembourg and the United Kingdom), the South-East European countries (the Czech Republic, Estonia, Poland, the Slovak Republic and Slovenia) as well as non-EU countries (Canada and Iceland). These countries represent different levels of socio-economic development and, as a result, the variety of situations concerning the distribution of income.
\end{abstract}

JEL classification: H21, H23, H24

Keywords: redistribution, progression, tax policy 


\section{INTRODUCTION}

There is strong evidence that the level of income disparities has grown over the last 2-3 decades in almost all OECD countries. Over the period $1985-2011^{1}$ the most popular measure of the phenomenon - the standard Gini coefficient - has risen significantly in Denmark, Finland, Norway, Sweden, Germany, Italy, Luxembourg, the United Kingdom, the Czech Republic, Hungary, New Zealand, Japan, Canada, the United States, Mexico and Israel (OECD, 2015). In each of these counties the increase exceeded 3 p.p., which accounted for more than 10 per cent of the initial value of the index (with the exception of New Zealand, the United States and Mexico, where the rise in Gini was 6-10 per cent). At the same time, little change in equality measured by the same indicator has been noted in Belgium, France and the Netherlands - the rise in the Gini stood at respectively - 0,9 p.p., 0,6 p.p. and 0,8 p.p, which amounts to $2,5-3 \%$. The value of the Gini has shrunk only in Greece and Turkey, although the scale of the reduction was marginal.

A similar trend has been observed in the field of poverty. The number of people at risk of poverty, on the assumption that the poverty line stands at 60 per cent of medium average earnings has risen by 2 p.p. (OECD-wide average) in the 21st century - from 15,4 per cent in 2001 to 17,5 per cent in 2012 (OECD, 2015).

At the same period the ratio of the top 20 per cent of the population's disposable income to the bottom 20 per cent's disposable income ( $\$ 80 / S 20$ quantile share) has grown from 4,6 to 5,3 (OECD, 2015).

A certain level of income inequalities seems to be desirable in the market economy. It creates incentives to undertake more effort - to educate, improve occupational qualifications, develop businesses, work harder and more efficiently. In some literature (e.g. Woźniak, 2012, p. 205-218) we can find distinctions between "activating" and "frustrating" inequalities. Income disparities have an "activating" character when they act as a driver of initiatives, whereas "frustrating" inequalities deprive economic agents of internal motivation.

The second type of inequalities may have a negative impact on society and to some extent it may be harmful to the economy. There is a wide consensus that a high level of income inequalities can raise social conflicts. J.K. Galbraith (1996, p. 62-63) warned of the excessive spread between the richest and the poorest. He claimed that "the more unequal the distribution of income is, the more dysfunctional it becomes". It is considered that the excessive spread between the extremities of the poor and the wealthy may cause social unrest, strikes or even rebellion (Moździerz, 2012, p. 532).

Moreover, there is a strong evidence that a high level of income inequality affects economic growth. The latest OECD analysis suggests that the rise in the Gini by 3 points would reduce GDP by 0,35 percentage points per year over 25 years. The cumulative negative impact seems to be significant - 8,5 per cent GDP loss at the end of the period (OECD, 2014b, 2).

Hence it is crucially important to properly define and pursue the policy of mitigating income social inequalities, in particular in the field of income distribution. This policy covers fiscal instruments in the form of public expenditures (mainly social transfers) as well as taxes (especially direct taxation).

\section{The impact of tax systems in mitigating income disparities in OECD countries}

Measuring the impact of fiscal policy on the level of income dispersion is possible by comparing the value of income distribution indicators before taxes and transfers to their value after taxation and social expenditures.

In the period 2004-2012 the OECD-wide average difference between the poverty rates before and after taxation (poverty rate: 60 percent) have ranged from 15,2 p.p. in 2007 to 17,8 p.p. in 2009 (Figure 1). It means the reduction in the number of people at risk of poverty by 48 51 per cent.

In 2012 in countries such as Finland, Ireland, France, Hungary and the Czech Republic the reduction of the poverty rate due to taxes and transfers amounted to more than 60 per cent of the indicator's initial value. It was slightly less than 60 per cent in Germany, Austria, Luxembourg and the Slovak Republic. For the most numerous group of countries the scale of the reduction was close to 50 per cent (slightly less or slightly above the line) - the group covers Italy, Greece, Belgium, Netherlands, Denmark, Iceland, Norway, Poland, Slovenia, Portugal, Spain, Turkey and the United Kingdom. The mitigation of the scale of poverty due to fiscal instruments is definitely lower in non-European countries (Australia, New Zealand, the United States, Israel, Mexico, Korea and

12011 or latest data - if available.

The article is an effect of the project - „Financialization- impact on the economy and society”- international conference, conducted by the University

of Information Technology and Management in Rzeszów with Narodowy Bank Polski under the scope of economic education programme 
Figure 1: The level of income inequalities in OECD countries

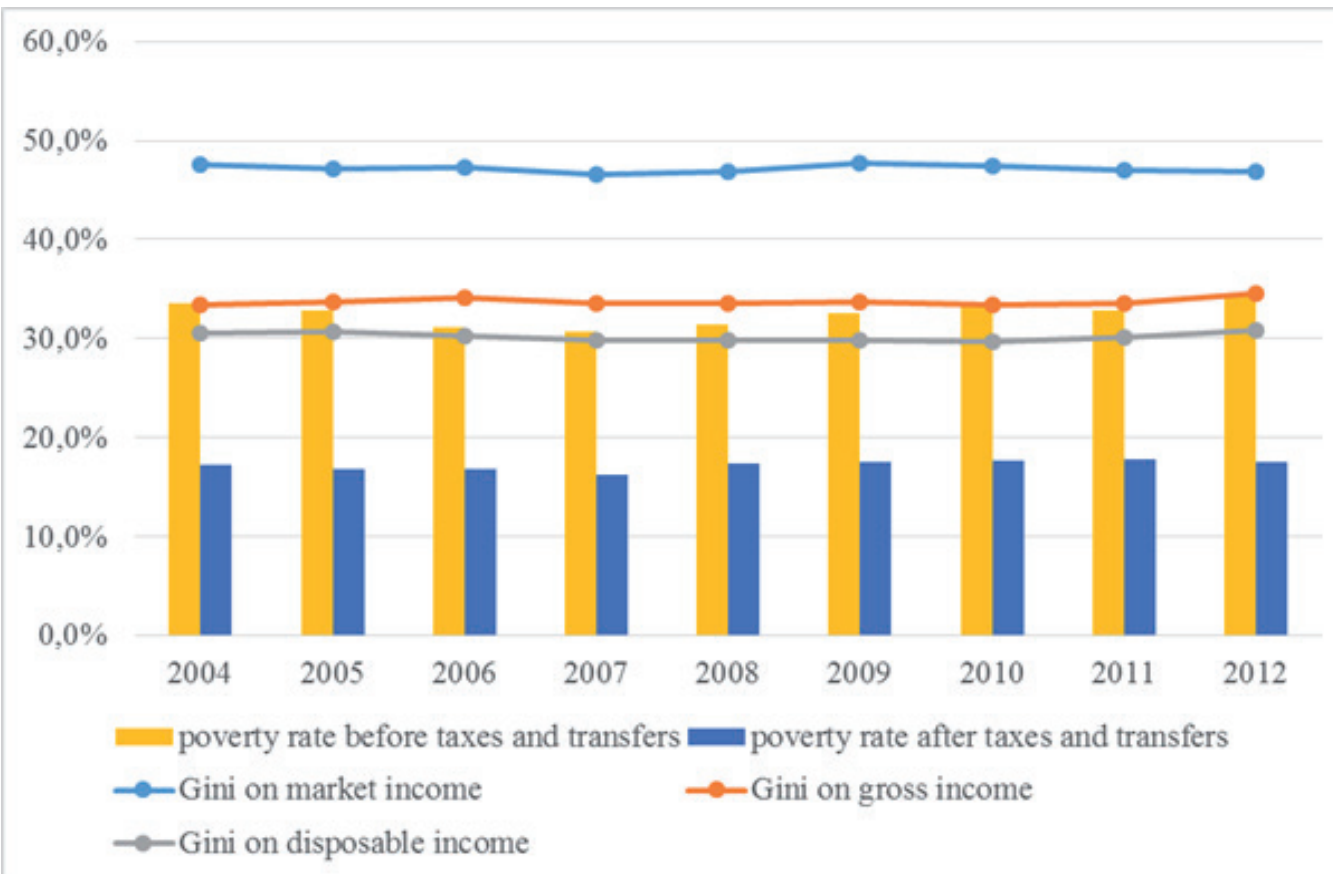

Source: OECD (2015a)

Turkey-respectively 30,31, 27, 19, 10, 6 and 5 per cent of the poverty rate before taxes and transfers).

The analogical comparison can be applied to the Gini coefficient. From this perspective, it is justified to compare the Gini for the gross market income (before taxes and transfers) with its value for disposable income (after taxes and transfers). As you can see in Figure 1 the second indicator seems to be definitely lower, although the reduction level varies significantly among the OECD countries. The difference ranges from 2-3 p.p. in Turkey and Korea to 11 - 13 p.p. in New Zealand, the United States, Canada, Australia and Mexico to more than 20 p.p. for the majority of the "old" members of the European Union like Austria, Belgium, Luxembourg, Finland, France, Germany, Greece, and Ireland. A similar level of difference between these two indicators are characteristic to some emerging economies, such as Slovenia, Hungary and the Czech Republic. In Poland, Estonia, Denmark, Sweden, Norway, Italy and Spain the Gini coefficient on income is reduced by 13-19 p.p. due to fiscal instruments. The data confirms the presence of a broadly-defined fiscal policy in the area of the income redistribution in OECD countries.

As mentioned, policy contains two groups of fiscal instruments - public expenditures in the form of social transfers and taxes - especially of a progressive schedule. OECD countries vary significantly in terms of these instruments' influence on income distribution
(Hoeller et al., 2012, p. 24). In Sweden, Norway, Iceland, Switzerland and Denmark the labour income distribution seems to be quite even, with a considerable level of social transfers and mild progressive personal income taxes. In Finland, France, Italy Belgium, Estonia, the Czech Republic, the Slovak Republic and Slovenia labour income inequalities are on the average OECD level, accompanied by a considerable unemployment rate. Fiscal policy of these countries can be characterised by a moderately progressive tax schedule and low social transfers. Another group contains countries with a relatively high level of income disparities as well as high unemployment rate, i.e.: Luxembourg, Germany, Austria, Spain, Greece, Hungary, Poland, Japan and Korea. Income tax ranges in these countries seem to be moderately progressive, while social transfers are relatively high. Ireland, the Netherlands, the United Kingdom, Australia, New Zealand and Canada are characterised by a considerable level of labour income inequality. These countries carry out fiscal policy based on both - expenditure and tax instruments with the same meaningful impact of them. The level of income progression in these countries is considerably high, although the amounts of social transfers are also significant. The level of income inequalities measured by the Gini is the highest in the United States. Its value is higher than the OECD-wide average also in Portugal, Turkey, the United States, Chile, Mexico and Israel. Fiscal

The article is an effect of the project - „Financialization- impact on the economy and society"- international conference, conducted by the University of Information Technology and Management in Rzeszów with Narodowy Bank Polski under the scope of economic education programme 
Table 1: The impact of fiscal policy on the level of income disparities measured by the changes in the Gini coefficient -2011 or latest

\begin{tabular}{|c|c|c|c|}
\hline Specification & $\begin{array}{l}\text { Gini on marked income } \\
\text { minus Gini on disposable } \\
\text { income } \\
\text { (1) }\end{array}$ & $\begin{array}{l}\text { Gini on gross income } \\
\text { minus Gini on disposable } \\
\text { income } \\
(2)\end{array}$ & $2 / 1$ \\
\hline Austria & 0,219 & 0,047 & $21,50 \%$ \\
\hline Belgium & 0,220 & 0,045 & $20,50 \%$ \\
\hline Canada & 0,123 & 0,042 & $34,10 \%$ \\
\hline Czech Republic & 0,199 & 0,034 & $17,10 \%$ \\
\hline Denmark & 0,187 & 0,041 & $21,90 \%$ \\
\hline Estonia & 0,151 & 0,025 & $16,60 \%$ \\
\hline Finland & 0,228 & 0,044 & $19,30 \%$ \\
\hline France & 0,212 & 0,037 & $17,50 \%$ \\
\hline Germany & 0,212 & 0,056 & $26,40 \%$ \\
\hline Greece & 0,229 & 0,036 & $15,70 \%$ \\
\hline Iceland & 0,142 & 0,037 & $26,10 \%$ \\
\hline Ireland & 0,278 & 0,075 & $27,00 \%$ \\
\hline Israel & 0,110 & 0,048 & $43,60 \%$ \\
\hline Italy & 0,182 & 0,038 & $20,90 \%$ \\
\hline Luxembourg & 0,200 & 0,034 & $17,00 \%$ \\
\hline Netherlands & 0,121 & 0,050 & $41,30 \%$ \\
\hline New Zealand & 0,128 & 0,027 & $21,10 \%$ \\
\hline Norway & 0,157 & 0,044 & $28,00 \%$ \\
\hline Poland & 0,167 & 0,014 & $8,40 \%$ \\
\hline Portugal & 0,198 & 0,050 & $25,30 \%$ \\
\hline Slovak Republic & 0,162 & 0,010 & $6,20 \%$ \\
\hline Slovenia & 0,216 & 0,054 & $0,00 \%$ \\
\hline Spain & 0,176 & 0,037 & $21,00 \%$ \\
\hline Sweden & 0,157 & 0,030 & $19,10 \%$ \\
\hline Switzerland & 0,083 & 0,000 & $0,00 \%$ \\
\hline United States & 0,123 & 0,097 & $78,90 \%$ \\
\hline Average & 0,176 & 0,040 & $22,90 \%$ \\
\hline
\end{tabular}

Source: Own calculations based on OECD (2015a)

policy (both expenditure and tax instruments) does not have a material impact on the income distribution there.

Quantification of the impact of the tax system on income distribution is possible due to comparing the Gini for gross income (after transfers but before taxation) and an analogous indicator for disposable income (Table 1). The changes in the value of the Gini resulted in a taxation range between 0 in Switzerland, 1 p.p. the Slovak Republic, 1,4 p.p. in Poland, 2,5 p.p. in Estonia and 2,7 p.p. in New Zealand to 3-5 p.p. in Sweden, Luxembourg, Spain, France,
Iceland, Greece, Italy, Denmark, Canada, Finland, Norway, Belgium and the Netherlands. For Germany and Slovenia it is estimated that taxation contributes to the reduction in the Gini of more than 5 p.p. In the United States and Ireland tax systems have special redistribution properties - the reduction in the Gini due to them accounted for at least 7,5 p.p.

The data presented in Table 2 can be used to quantify the impact of the tax instruments on income disparity mitigation expressed by the difference between the level

The article is an effect of the project - „Financialization- impact on the economy and society"- international conference, conducted by the University of Information Technology and Management in Rzeszów with Narodowy Bank Polski under the scope of economic education programme 
of income dispersion measured by the Gini coefficient. What is more, it also evaluates the importance of taxes among other fiscal instruments in the policy of mitigating income disparities according to the formula:

$$
I T S=\frac{G o G I-G o D I}{G o M I-G o D I} \times 100 \%
$$

where:

ITS = the share of the redistribution al effect of tax system in the whole redistribution al effect of fiscal policy - impact of tax system,

GoGl= Gini on gross income,

GoDI = Gini on disposable income,

GoMI = Gini on marked income.

For the vast majority of countries the tax system contributes to $15-30 \%$ of the whole fiscal redistribution effect. The ratio is higher only in four OECD countries (Canada, the Netherlands, Israel, the United States). It is worth mentioning that only in the United States taxes contribute more to the reduction of income inequalities than social transfers.

It confirms assumptions contained in the literature that in OECD countries $75 \%$ of the reduction is due to transfers and the rest due to direct household taxation (OECD, 2012, p. 3).

\section{The role of different tax categories in narrowing income disparities - theoretical background}

To properly assess the performance of the compensatory function we should consider the impact of a tax system as a whole as well as the impact in terms of individual taxes. The role of the individual constructions in the narrowing of income inequalities vary in terms of direction and strength of interaction. There is a possibility that their reciprocal relation would be multidirectional. As a result, such stimuli may strengthen or weaken certain phenomena, depending on the types of interactions. According to A. Walasik (2008, p. 60) the redistribution of income can be realised by both direct and indirect measures. The first group includes revenue collection instruments and public expenditures which adjust the level of the disposable income of economic agents - especially of individuals and corporations - e.g. direct taxation, social transfers and liabilities from social security schemes. The second group of measures refers to instruments which affect the level of income utility. It contains indirect taxes as well as the sums spent by the public sector on financing pure public goods and social goods. Taking into account the presented classification we can state that the redistribution/compensatory function of public finance can be carried out by both types of taxes distinguished according to the criterion of tax shiftability direct and indirect taxes.

Direct taxes, especially the level of Personal Income Tax and Corporate Income Tax liabilities, are factors determining the level of the disposable income, i.e. the sum that can be spent on consumption or investment demand. Meanwhile, indirect taxes, especially Value Added Tax or excises, influence the level of goods and services prices and as a result influence the level and structure of household consumption.

Personal Income Tax is perceived as a basic tax

Table 2: The Gini coefficient between the impact of tax policy on the narrowing of income disparities (measured by the difference between the Gini on gross income and the Gini on disposable income) and the share of different categories of taxes in tax revenues (SSC not contained in tax revenues)

\begin{tabular}{|c|c|c|c|c|c|c|}
\hline Specification & $\mathbf{2 0 0 8}$ & $\mathbf{2 0 0 9}$ & $\mathbf{2 0 1 0}$ & $\mathbf{2 0 1 1}$ & $\mathbf{2 0 1 2}$ & $\begin{array}{c}\mathbf{5 - y e a r} \text { arithmetic } \\
\text { average }\end{array}$ \\
\hline $\begin{array}{c}\text { taxes on income, profits and capi- } \\
\text { tal gains of individuals (1110) }\end{array}$ & 0,222 & 0,415 & 0,556 & 0,54 & 0,562 & 0,459 \\
\hline $\begin{array}{c}\text { taxes on income, profits and capi- } \\
\text { tal gains of corporations (1120) }\end{array}$ & 0,013 & $-0,203$ & $-0,228$ & $-0,162$ & $-0,264$ & $-0,169$ \\
\hline taxes on property (4000) & 0,206 & 0,217 & 0,298 & 0,346 & 0,198 & 0,253 \\
\hline taxes on goods and services (5000) & $-0,359$ & $-0,45$ & $-0,491$ & $-0,489$ & $-0,418$ & $-0,441$ \\
\hline general taxes on goods and servi- & $-0,287$ & $-0,417$ & $-0,489$ & $-0,506$ & $-0,395$ & $-0,419$ \\
\hline ces (5110) & $-0,31$ & $-0,341$ & $-0,485$ & $-0,44$ & $-0,434$ & $-0,402$ \\
\hline excises (5120) & 0,137 & 0,288 & 0,437 & 0,439 & 0,37 & 0,334 \\
\hline
\end{tabular}

Source: Own calculations based on OECD (2015b)

The article is an effect of the project-„,Financialization- impact on the economy and society”- international conference, conducted by the University of Information Technology and Management in Rzeszów with Narodowy Bank Polski under the scope of economic education programme 
instrument that regulates the level of disposable income of individuals. In the vast majorities of OECD countries its construction is still based on the progressive schedule, in spite of some reversed tendencies in recent years (European Commission 2014, p. 28-30). Nowadays only Estonia, Hungary and the Czech Republic use one tax bracket in the construction. The single-rate formula was temporarily introduced in Iceland (2007-2010) and the Slovak Republic (2014-2012). These countries resigned from the schedule because of insufficient tax collection. The average PIT rate for the person whose income stands at 167 per cent of the average wage on the assumption that the person is single and does not have any children exceeds the analogous rate for the person in the same situation whose income is on the level of 67 per cent in all but one OECD countries. In some countries, the difference between these two rates seems to be marginal (e.g. Poland, Chile, Estonia) and is lower that 2 p.p., although in some "old" member of the EU (the Netherlands, Ireland, Sweden, Portugal, Greece, Italy) its value is over 15 p.p. Only in Hungary the PIT burden does not differentiate with the level of income (OECD, 2015d).

In 2014 the average number of central PIT tax brackets in the OECD stood at 5 . As mentioned, in the last two-three decades there has been a widespread trend in flattening PIT scales as well as in making their constructions more neutral. In 1980 it was common for OECD countries to have 14 tax brackets (OECD, 2015c). Despite this fact, it should be emphasized that the character of the PIT scale does not prejudge the redistribution properties of the tax construction. Other important factors are also: the level of the tax rates, their relations and some other instruments that reduce taxpayers' tax liabilities (Paturot, Mellbye, and Brys, 2013, p. 4). The most important among them seem to be special provisions which exempt the initial level of income from taxation. Its justification is that a minimum of marked income should be free of tax because it is spent on necessities. The instrument could be a powerful tool of mitigating income disparities, especially in the area of poverty reduction, if the value of the income exempted from tax is linked to the minimum subsistence figure. Other compensatory instruments used in PIT constructions in the OECD contain tax allowances or tax credits.

This form of tax expenditures takes one of the three possible forms: a zero-rate tax bracket, a basic personal

Figure 2: The relationship between the impact of tax policy on narrowing income disparities (measured by the difference between the Gini on gross income and the Gini on disposable income) and the share of taxes on income, profits and capital gains of individuals in total taxes - scatter diagram

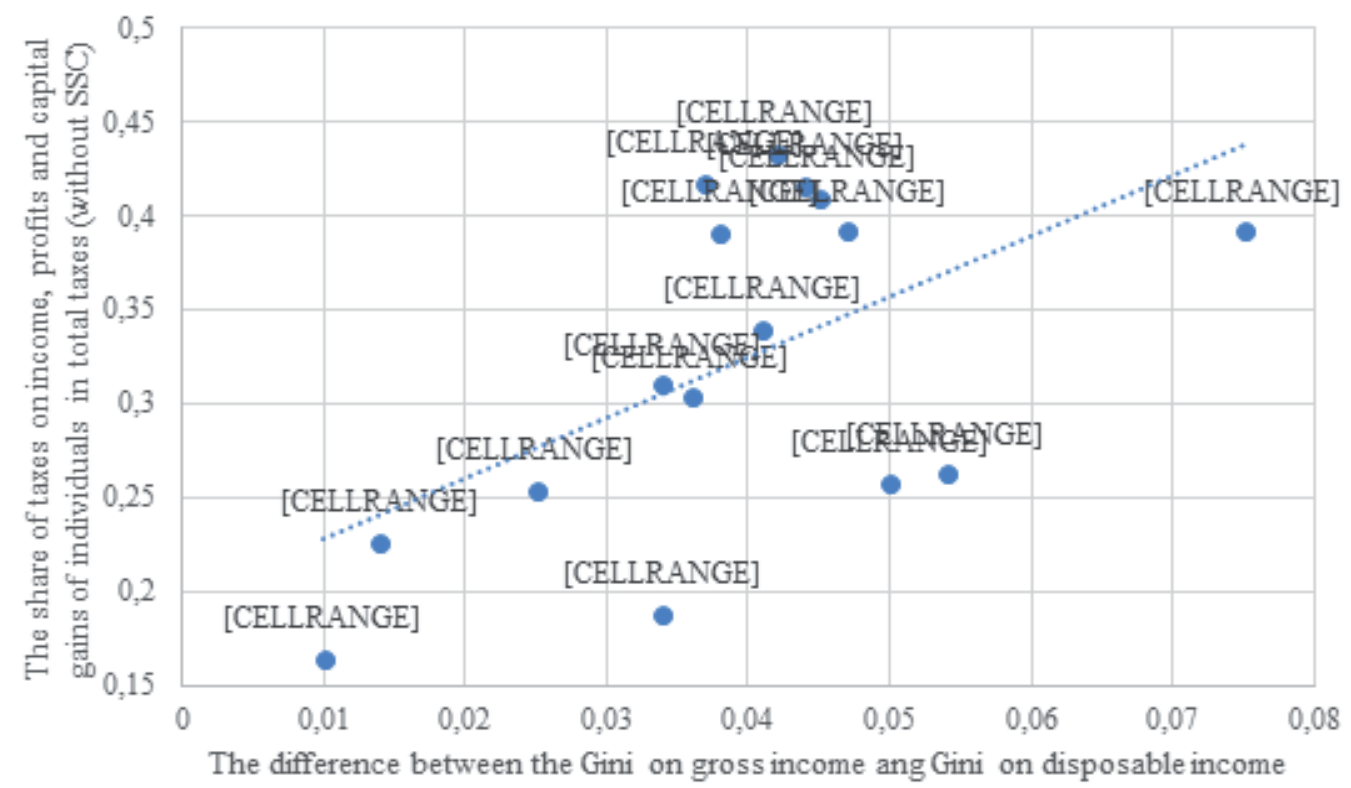

Source: Own calculations based on OECD (2015a), OECD (2015b)

AU - Austria, BE - Belgium, CA - Canada, CZ - Czech Republic, ES - Estonia, FI - Finland, GR - Greece, IC - Iceland, IR Ireland, IT - Italy, LU - Luxembourg, SR - the Slovak Republic, SL - Slovenia, UK - the United Kingdom

The article is an effect of the project - „Financialization-impact on the economy and society”- international conference, conducted by the University of Information Technology and Management in Rzeszów with Narodowy Bank Polski under the scope of economic education programme 
allowance or a tax credit. In 2010 this instrument functioned in the PIT systems of all but four OECD countries - with the exception of Hungary, Mexico, Turkey and New Zealand. In Australia, Ireland, Sweden, Norway, the United Kingdom, the Slovak Republic and Slovenia its redistributive effect is strengthened by the changes in the exempted minimum with the level of income (Torres, Mellbye and Brys, 2012, p. 21).

The construction of PIT as a personal tax gives some possibilities to adjust the tax burden to an individual tax capacity. It enables reduction of the tax liability due to marital or family status, some health problems or other important features of a given taxpayer. Although it is widely discussed whether Personal Income Tax construction should be family-oriented, nowadays all OECD countries reduce the tax burden if, for example, a taxpayer has a spouse and two children. The scale of the reduction is comparable in all countries of the Organisation.

It is thought in the literature that property taxes with properly defined structure can be progressive, because they are borne mainly by capital and land owners, who are predominantly higher-income individuals. Properly administered property tax can give the means of addressing vertical equity concerns (Norregaard, 2013, p. 17-19).

Although there is a wide consensus that the impact of immovable property taxes on income distribution, it depends on the character of the tax base used in a particular construction. Property taxes with the area basis are perceived as unfair (Etel \& Dowgier, 2013, p. 14). If an immovable property tax would perform in mitigating income inequalities, the construction should be based on the cadastral value of the property - the capital value or the annual rental value. Even though in most OECD countries immovable property taxes have a cadastral formula, in some of them (e.g. Poland, the Czech Republic, Israel) the level of the tax liability depends mainly on the area basis (Almy, 2014, p. 7).

Value Added Tax (or Sales Taxes in the USA) and excise duties on basic energy sources are perceived as regressive constructions. They have been described as unfair since the 19th century (Gaudemet \& Molinier, 2000, p. 496). It is a wide consensus that they absorb a relatively larger portion of the income of poorer members of society compared to the better-off. Some special provisions in the form of preferential rates and tax exemptions are used in constructions of these taxes in order to mitigate the regressive impact of them. Another aim of their implementation is that they promote consumption of merit goods (i.e. culture events).

The use of tax expenditures in consumption taxes is very common. In OECD countries, the average effective VAT rate on households is equal to $1 / 2$ of the standard VAT rate (CASE, 2013, p. 12). As a result, the collection

Figure 3: The relationship between the impact of tax policy on narrowing income disparities and the share of taxes on income, profits and capital gains of corporations in total taxes - scatter diagram

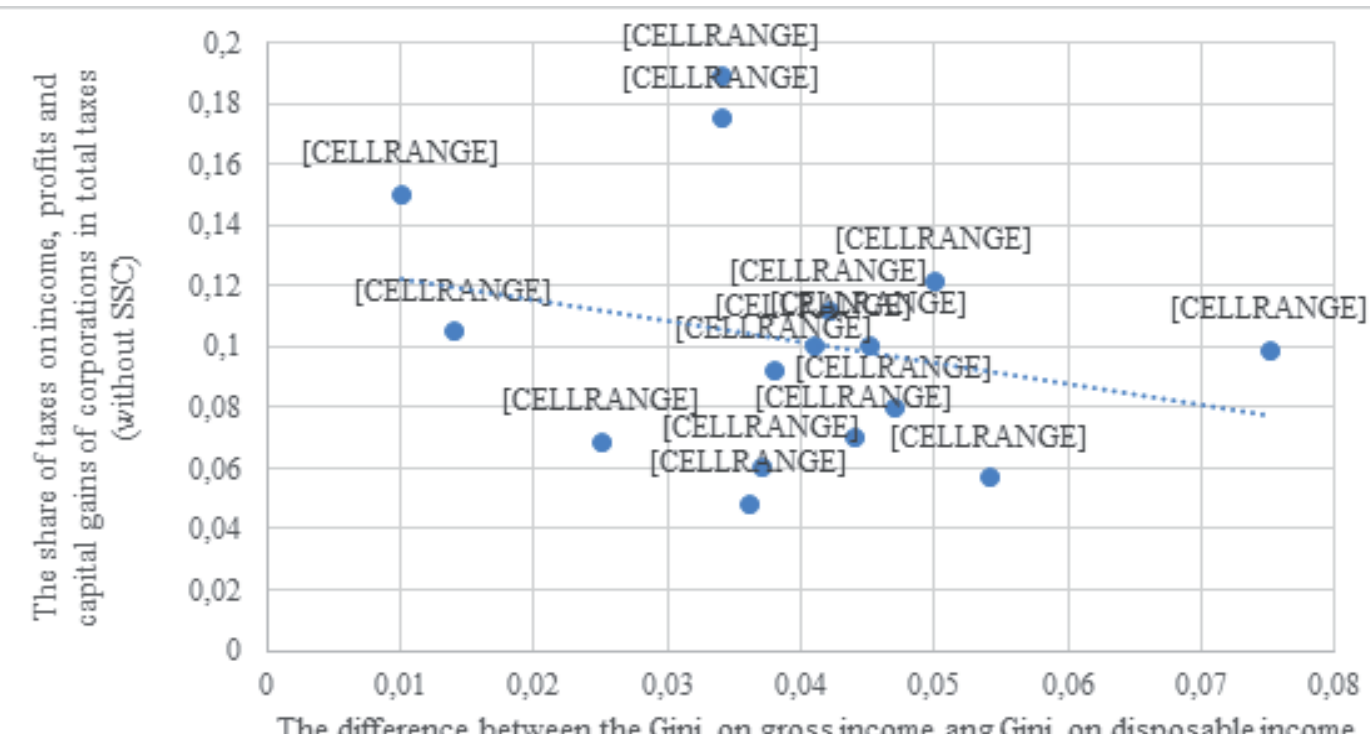

Source: Own calculations based on OECD (2015a), OECD (2015b)

The article is an effect of the project -, Financialization- impact on the economy and society"- international conference, conducted by the University of Information Technology and Management in Rzeszów with Narodowy Bank Polski under the scope of economic education programme 
Figure 4: The relationship between the impact of tax policy on narrowing income disparities and the share of taxes on property in total taxes - scatter diagram

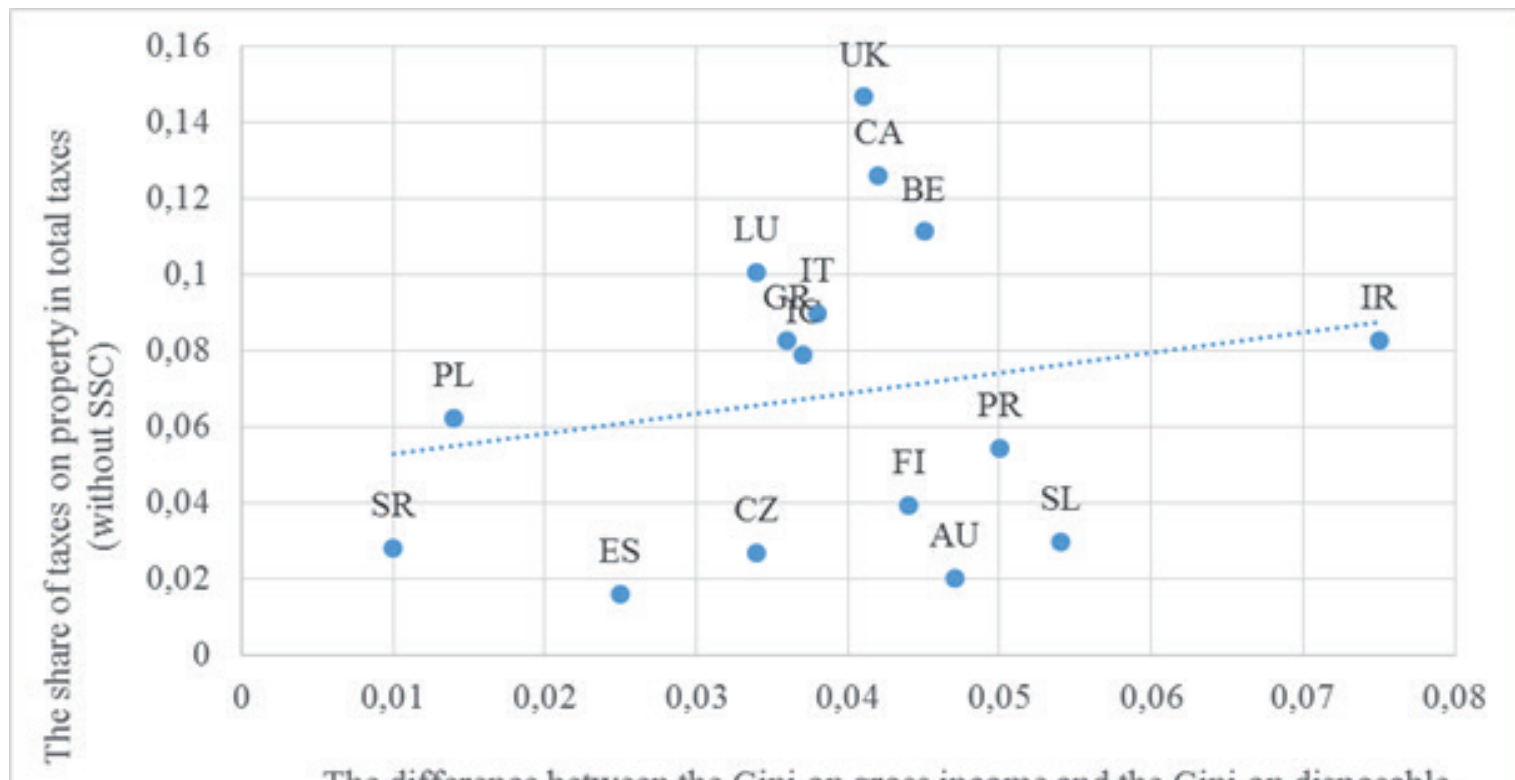

The difference between the Gini on gross income and the Gini on disposable income

Source: Own calculations based on OECD (2015a), OECD (2015b)

of VAT revenues is far lower than it could be if the whole consumption was charged by the standard rate. The phenomenon can be confirmed by the VAT Revenue Ratio indicator. The OECD-average value of it is close to 50 per cent, which means that the loss in VAT revenues is close to 50 per cent of its potential value - due to tax fraud and tax preferences (OECD, 2014a, p. 94-98).

There is a serious doubt as to whether the special

Figure 5: The relationship between the impact of tax policy on narrowing income disparities and the share of taxes goods and services in total taxes - scatter diagram

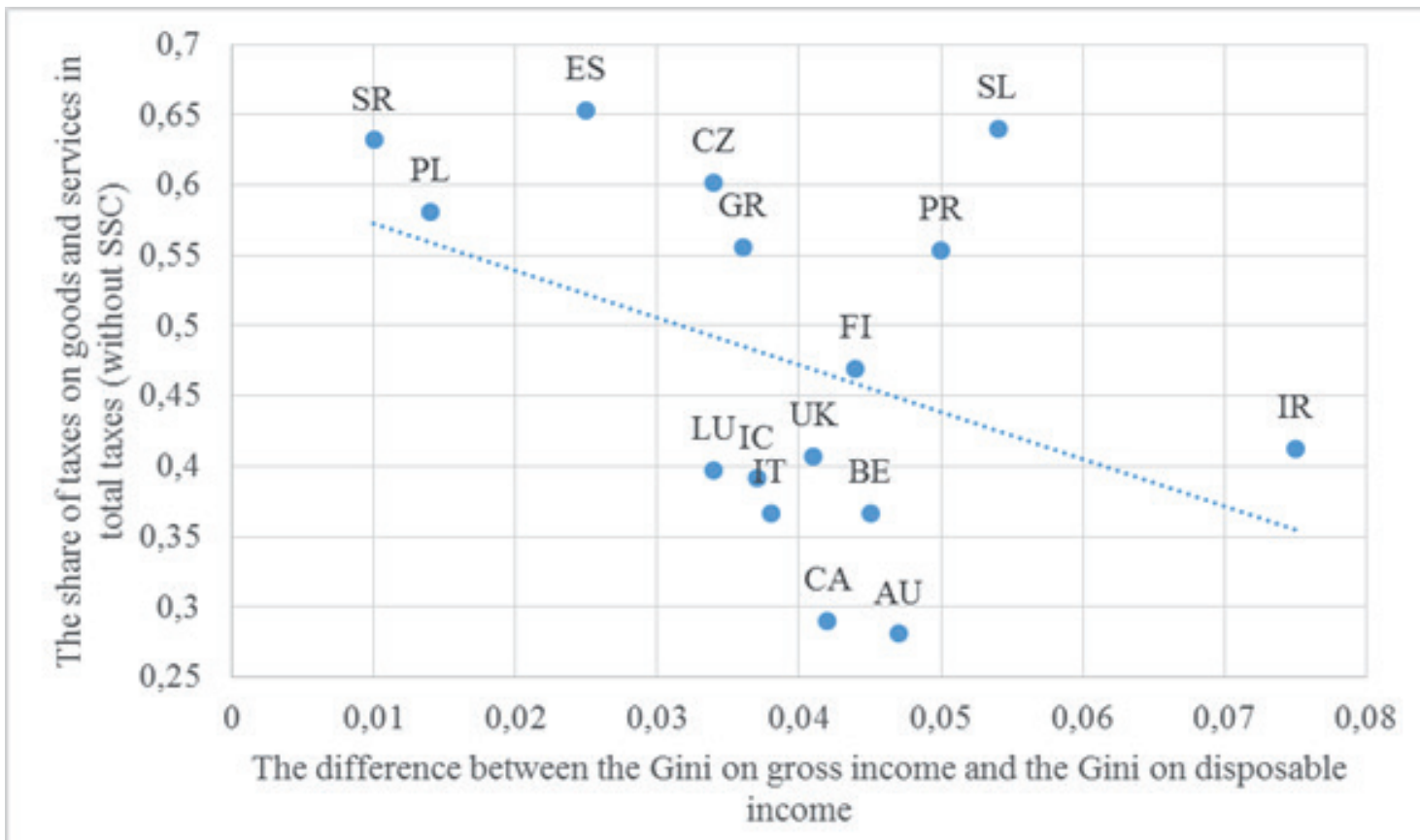

Source: Own calculations based on OECD (2015a), OECD (2015b)

The article is an effect of the project - „Financialization- impact on the economy and society”- international conference, conducted by the University of Information Technology and Management in Rzeszów with Narodowy Bank Polski under the scope of economic education programme 
Figure 6: The relationship between the impact of tax policy on narrowing income disparities and the share of general taxes on goods and services in total taxes - scatter diagram

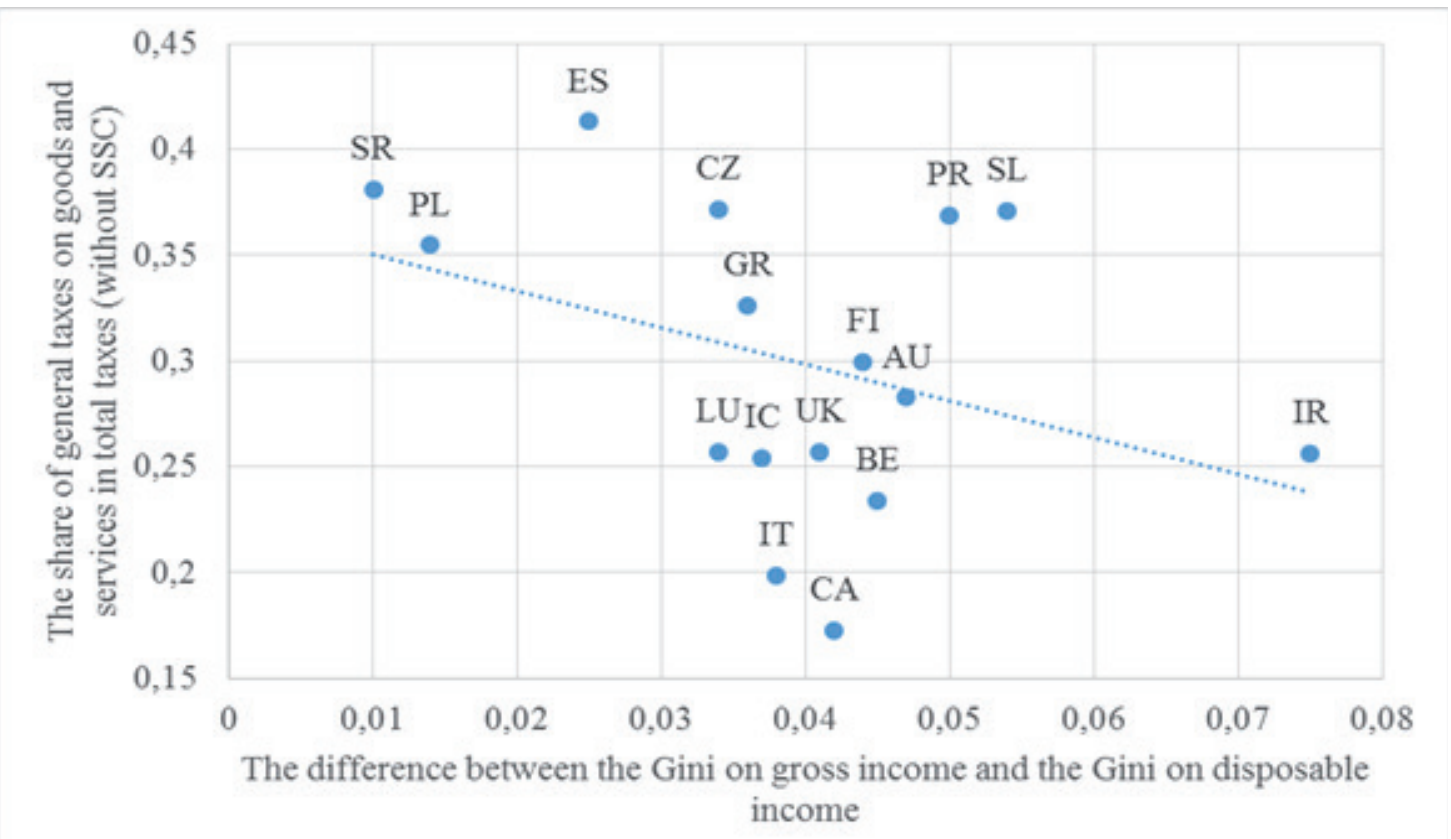

Source: Own calculations based on OECD (2015a), OECD (2015b)

Figure 7: The relationship between the impact of tax policy on narrowing income disparities and the share of excises in total taxes - scatter diagram

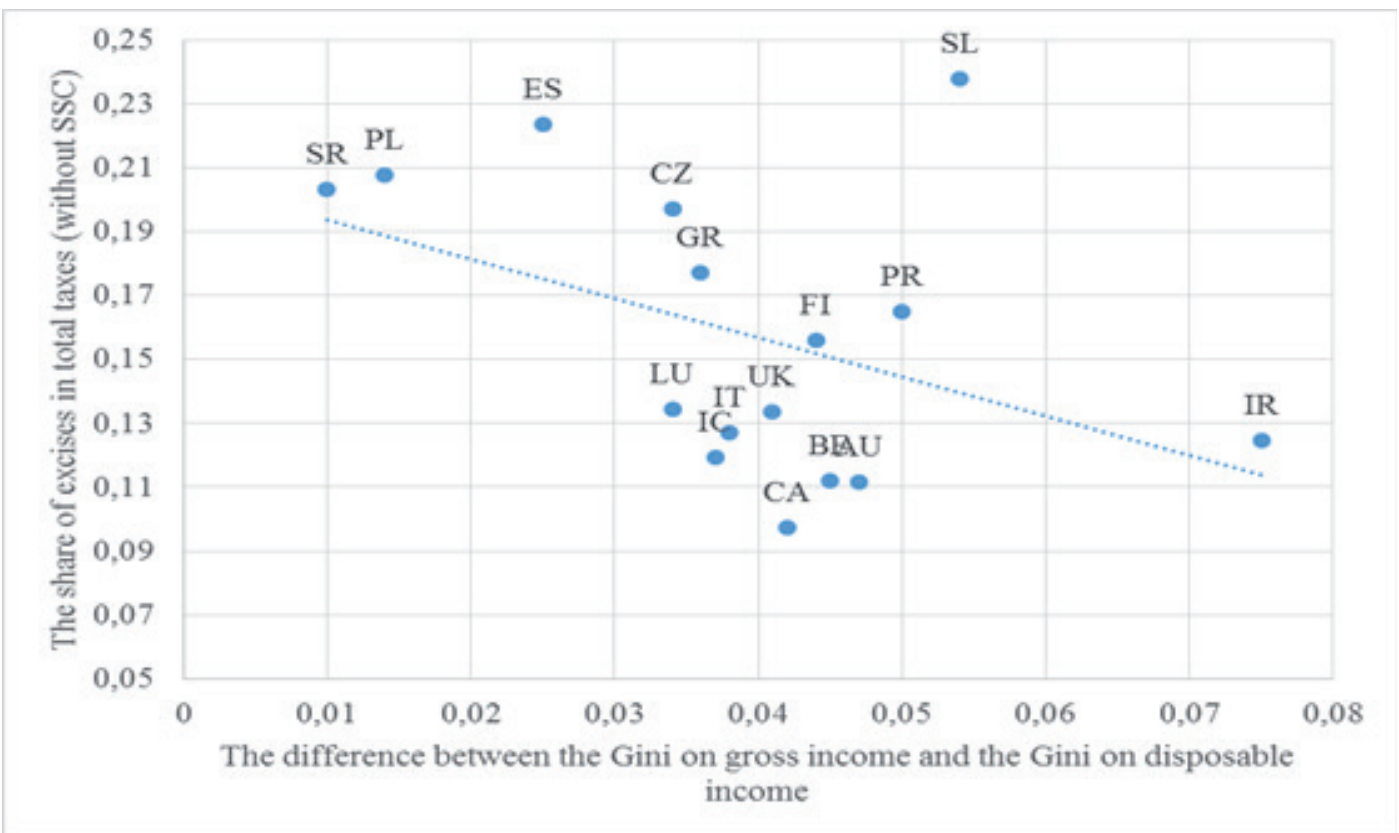

Source: Own calculations based on OECD (2015a), OECD (2015b)

The article is an effect of the project - „Financialization- impact on the economy and society”- international conference, conducted by the University of Information Technology and Management in Rzeszów with Narodowy Bank Polski under the scope of economic education programme 
provisions described above are an effective way of mitigating income inequalities. Copenhagen Economics (2007, p. 28-31) claims that it is justified to differentiate the burden of taxes on general consumption in countries where consumption patterns vary significantly between different economic groups. However, OECD countries are classified as developed economies and consequently the structure of consumption on the area of a single country is similar. In these circumstances instruments like VAT exemptions and VAT reduced rates benefit not only poorer inhabitants of a given country, but also the well-off. Wealthy people acquire the same types of preferentially taxed goods and services as poorer members of the society, but often in bigger amounts. Consequently, they benefit from the tax preferences. The phenomenon is known as the "Matthew effect" and it results in a high level of mechanical deadweight loss (Warrren, 2008, p. 21-27). Owing to this, VAT exemptions and reduced rates are perceived as insufficient instruments. According to some literature (European Commission, 2011, p. 61) it is only justified to reduce VAT rates on necessities and some basic services (i.e. electricity, heating). Spending on these categories of goods and services creates a relatively larger portion of the worse-off consumption compared to the well-to-do.

In order to assess the relation between the structure of a tax mix, i.e. the share of different tax categories in total tax revenues and the impact of the tax system on narrowing income disparities, counted according to the formula (1), the Gini coefficients have been calculated and scatter diagrams have been developed (Figure 2-7).

The conclusions from the analysis are as follows:

1) there is a moderate positive correlation between the share of Personal Income Taxes in tax revenues and the reduction of income inequalities due to the tax system - according to the formula 1 ,

2) there is a moderate negative correlation between the share of consumption taxes in the tax mix and the impact of tax policy on narrowing income disparities - nearly equally to general taxes on goods and services (Value Added Tax in all but one OECD country and Sales
Taxes in the United States),

3) there is a weak positive correlation between the level of fiscalism (measured by the relation between total tax revenues) and the role of the tax system in mitigating income inequalities,

4) there is no general correlation between the share of corporate income taxation and the role of taxes in reducing the level of income disparities; a similar conclusion can be applied to the share of property taxes in a tax mix.

The conclusions described above confirm the presumptions emerging from a review of the literature.

\section{Conclusions}

OECD countries widely use fiscal policy in the redistribution of income. As a result, the level of income dispersion as well as the number of people at risk of poverty after taxes and transfers is far lower than its initial value. Among different fiscal instruments taxes play an important role. However, their impact on reducing income disparities make up only about one fourth of the whole redistribution effect of fiscal policy. This confirms that the material role in the compensatory function is played by social transfers, although taxes can supplement it.

The impact of different taxes on the distribution of income is highly diverse due to its direction and strength. The construction of a Personal Income Tax - the basic tax imposed on the income of individuals - has the greatest scope for personalisation, e.g. the adjustment of the tax burden to an individual's tax capacity. There is no doubt that consumption taxes - both of the main categories - the Value Added Tax and excise duties - tend to be regressive.

The analysis conducted in the article confirms that a high redistributive effect of a tax system is accompanied by a relatively large share of taxes on personal income in tax revenues as well as a relatively low share of consumption taxes (Value Added Tax/Sales Taxes and excises) in a tax mix.

The article is an effect of the project - „Financialization- impact on the economy and society"- international conference, conducted by the University of Information Technology and Management in Rzeszów with Narodowy Bank Polski under the scope of economic education programme 


\section{REFERENCES}

Almy, R. (2014). Valuation and Assessment of Immovable Property. OECD Working Papers on Fiscal Federalism, no. 19, OECD Publishing.

CASE (2013). Study to Quantify and Analyse the VAT Gap in the EU-27 Member States. Final Report. Warsaw.

Copenhagen Economics (2007). Study on Reduced VAT Applied to Goods and Services in the Member States of the European Union. Final report. 6503 DG TAXUD.

European Commission (2011). Tax Reforms in EU Member States 2011. Tax Policy Challenges for Economic Growth and Fiscal Sustainability. Taxation Papers. no. 28, Luxembourg: Office for Official Publications of the European Communities.

European Commission (2014). Taxation Trends in the European Union. Data for the EU Member States, Iceland and Norway. Eurostat.

Etel, L., Dowgier, R. (2013). Podatki i opłaty lokalne. Czas na zmiany. Białystok: Wydawnictwo Temida 2.

Galbraith, J.K. (1996). The Good Society. The Humane Agenda. Boston New York: Hougson Mifelin Company.

Gaudemet, P.M., Molinier, J. (2000). Finanse publiczne. Warszawa: Polskie Wydawnictwo Ekonomiczne.

Hoeller, P., et al., (2012). Less Income Inequality and More Growth - Are They Comparable? Part 1. Mapping Income Inequality Across the OECD. OECD Economics Department Working Papers, no. 924, OECD.

Moździerz, A. (2012). Błędna polityka podatkowa przyczynq wzrastajq̨cych nierówności. In T. Famulska., A. Walasik (Ed.), Finanse w niestabilnym otoczeniu - dylematy i wyzwania. Finanse Publiczne. Katowice: Wydawnictwo Uniwersytetu Ekonomicznego.

OECD (2012). Income Inequality and Growth: The Role of Taxes and Transfers. OECD Economic Department Policy Notes, no. 9.

OECD (2014a). Consumption Tax Trends. VAT/GST and Excise Rates, Trends and Policy Issues, OECD Publishing.

OECD (2014b). Focus on Inequality and Growth. Does Income Inequality Hurt Economic Growth?, OECD Publishing.

OECD (2015a). OECD Social and Welfare Statistics. Wealth Distribution. Doi: 10.1787/socwel-data-en.

OECD (2015b). Income Distribution Database. Doi: 10.1787/data-00654-en.

OECD (2015c). OECD Tax Statistics. Doi: 10.1787/tax-data-en.

OECD (2015d). Taxing Wages. Comparative Tables. Doi: 10.1787/tax-data-en.

Norregaard, J. (2013). Taxing Immovable Property. Revenue Potential and Implementation Challneges. IMF Working Paper, no. WP/12/129, International Monetary Fund.

Paturot, D., Mellbye, K., Brys, B. (2013). Average Pesonal Income Tax Rate and Tax Wedge Progression in OECD Countries. OECD Taxation Working Papers, no. 15, OECD Publishing.

Torres, C., Mellbye, K., Brys, B. (2012). Trends in Personal Income Tax and Employee Social Security Constribution Schedules. OECD Taxation Working Papers, no. 12, OECD Publishing.

Walasik, A. (2008). Redystrybucyjna funkcja finansów publicznych w ujęciu teoretycznym. Katowice: Prace Naukowe Akademii Ekonomicznej im. K. Adamieckiego w Katowicach.

Warren, N. (2008). A Review of Studies on the Distributional Impact on Consumption Taxes in OECD Countries. OECD Social, Employmnet and Mitigation Working, Paris.

Woźniak, M.G. (2012). O potrzebie nowych procedur dla sprzeżeń między nierównościami społecznymi, kapitałem ludzkim i wzrostem gospodarczym. In Z. Sadowski (Ed.), Bogaci i biedni. Problemy rozwoju społeczeństwa polskiego. Warszawa: Polska Akademia Nauk. Komitet Prognoz "Polska 2000 Plus".

The article is an effect of the project - „Financialization- impact on the economy and society"- international conference, conducted by the University of Information Technology and Management in Rzeszów with Narodowy Bank Polski under the scope of economic education programme 